\title{
Teacher Quality and the Quality of Technical and Vocational Education and Training Courses: Implications for Sustainable Development in Cameroon
}

\author{
Godwill Mih Chewachong 1,2,3 \\ 1.Department of Agriculture, FASA, University of Dschang, P.O. Box 96, Dschang, Cameroon \\ 2.Inspectorate General of Education, Ministry of Secondary Education, Yaounde, Cameroon \\ 3.Faculty of Education, University of Cambridge, 184 Hills Road, Cambridge, CB2 8PQ, UK. \\ * E-mail of the corresponding author: chewachong01@gmail.com
}

\begin{abstract}
This research was supported by funds from the Cambridge Commonwealth, European and International Trust. Abstract

Teacher quality remains an important subject for debate and the role of TVET in reducing unemployment and facilitating sustainable development cannot be overemphasized. Here, we present a critical engagement with the literature on teacher quality; the quality of TVET courses and the implications these have for sustainable development. First, we trace the policy background and motivations that led to the introduction of TVET in Cameroon. Next a critical examination of what counts as teacher quality and yardsticks for defining teacher quality is provided. Further, there is a discussion on what TVET teacher training programs need, to be considered qualitative. Finally, focus is on the major issues in TVET teacher supply and quality, current pathways to TVET teaching in Cameroon, the resulting challenges and benchmarks. To ensure that Cameroon has suitably-skilled human capital, it is suggested that if diligently considered, the benchmarks could assist policy makers to design and implement quality TVET policies following the five steps proposed by the European Parliament and the Council of the European Union. These include, evaluating the existing situation of the TVET system, developing a strategy to reform the system, implementing the strategy, evaluating the impact and continuous monitoring and evaluation of performance in the sector.
\end{abstract}

Keywords: Teacher quality, TVET policy, Teacher training, Certification pathways, Sustainability

DOI: $10.7176 / \mathrm{JEP} / 12-2-01$

Publication date: January $31^{\text {st }} 2021$

\section{Introduction}

Cameroon's educational system like those of most African countries faces serious challenges. Poverty is widespread and remains the major cause of underdevelopment. There is an urgent need for educational reforms. The importance of quality education (SDG4) in achieving all seventeen sustainable development goals and bring poor resource countries like Cameroon out of poverty cannot be overemphasized. Quality education has been considered important to improve the quality of life (ILO, 1977) as it lays the foundation for the sustainable development of individuals and their society (Che, 2007; Krueger \& Lindahl, 2001; Zouliatou, 2017) through the development of skills (Tilak, 2002). Technical and Vocational Education and Training (TVET) also referred to as Career and Technical Education (CTE) is considered to be an effective means of developing the skilled manpower and technologies needed for effective participation in the work force (Mclean \& David, 2009; Okorafor \& Nnajiofo, 2017; UNESCO, 2002) as the demand for skilled professionals and technicians to take up TVET related jobs is on the increase (Hayward \& Homer, 2015).

It is understandable that changing industries should demand changing skills. However, while a number of sub-Saharan countries after independence (for example Ghana) focused on redefining their curricular to incorporate different versions of TVET to meet with increasing demands for skilled workers, Cameroon was lagging behind (Che, 2007). After realizing the importance of TVET to reduce unemployment and facilitate sustainable development, the urgency for quality TVET training courses and teachers is on the increase, since no educational system can rise above the quality of its teachers (Bigala, 2006; Cooper, 2006; Kajubi, 1971). The quality of the teacher is essential in improving the quality of school education and is in line with the No Child Left Behind Law that advocates for "highly qualified teachers"' in every classroom (Angrist \& Lavy, 2001; UNESCO, 2014). There is need therefore to gain a deeper understanding of teacher quality and quality TVET courses by engaging with the literature. Quality TVET teachers require good initial teacher training programs and constant reinforcement through In-Service Training (IST). All other things being equal (for example, adequate infrastructures, good salaries and balanced student teacher ratios), if you provide quality training to teachers by developing and equipping them with skills to help them cope with a rapidly changing environment and requirements for teaching, they should, in principle improve the quality of school education. 


\section{Policy Background}

Cameroon has a fragmented but unique educational system with a dual track that resulted from the English and French colonial models. It was on the $11^{\text {th }}$ of February 1961 following a UN sponsored plebiscite, when West and East Cameroon came together as one nation. This re-union in addition to bringing together West and East Cameroon that were separated following the defeat of Germany in World War One, meant the co-existence of two different educational systems (Ngoh, 2000) and the inevitable organizational and political complications that flow from such a situation. Today, several ministries are responsible for education: The Ministries of Basic Education, Secondary Education, Higher Education, Employment and Vocational Training, Agriculture, Culture, Public Works, and Youth. Inevitable organizational and political complexities flow from such a situation.

Even with this multiplicity of ministries to cater for education, the country suffers from a combination of skills mismatch, under qualification (GESP, 2010; World Bank, 2017) and a poor secondary technical education expansion policy, which makes it difficult to accelerate economic growth, eliminate unemployment, hunger, illiteracy and poverty (Efande, 2015). One way of solving this problem might be to improve both the access and quality of education. Quality education starts with the political will to enact appropriate, well defined policies and ensure proper implementation (Commission on the Private Sector, 2004).

The need for professionalizing education in Cameroon was expressed during the 1996 Education Forum. This increased the interest in TVET, considered by many as a means of facilitating the acquisition of professional skills that are relevant to the world of work (Afeti, 2010; Mclean \& David, 2009; UNESCO, 2002; UNESCO-UNEVOC, 2002). If this assumption is correct, nations should be encouraged to enact educational policies which guarantee quality TVET so that youths who are not interested or lack the means to engage in post-secondary education can gain the skills that are required for work (Sofoluwe, 2013). Further, TVET is thought to be more efficient if it matches the demands of the learners in terms of the sort of persons they want to be and the life they want to lead, with the skills and knowledge potential employers might be looking for (Oviawe et al., 2017; Yildirim \& Simsek, 1997).

Therefore, it is highly probable that it was the recognition of some of the opportunities TVET offers, and the need to respect international agreements to ensure sustainable development that motivated the establishment of a new education policy in Cameroon in 1998 (Tchombe, 2001). Also referred to as the Law of Educational Orientation, Law No 98/004 of 14 April 1998 lays down the Guidelines for Education in Cameroon. Part III - (3) of this law states that "in addition to general education, practical training shall be provided to students in vocational colleges and high schools, based on the courses they choose". Two important questions whose answers are not evident from this law are; how was the capacity in schools to be developed to implement the policy given that TVET is very expensive? Do the students and their parents have the opportunity to make informed choices and what happens if they choose poorly? True, each secondary school is, in principle supposed to have a guidance counsellor to provide proper career orientation to the students. But, most schools lack the capacity. Plus, most students enter TVET schools after primary education without ever meeting a counsellor, thus increasing the chances of them making uninformed or poor choices that can result to a mismatch between the demands of the learners and those of their potential employees. Whatever the case, the objective of TVET is to provide education and training which imparts knowledge and technical skills through formal, non-formal and informal education, with the hope of making the students fit for the world of work to ensure their economic sustainability (Ibrahim, \& Yasin, 2012; Marope, \& Holmes, 2015).

Further to the 1998 Law of Education Orientation, Cameroon developed a Poverty Reduction Strategy Program (PRSP) in 2003 which placed employment at the central stage and TVET as an important supplier of the skilled manpower. Seven years later (that is, in 2010), a report on the evaluation of the PRSP revealed that unemployment and weak productivity remained a concern. This could be a pointer to a possible mismatch between the types and quality of TVET programs offered and the skills and knowledge demand from potential employers (PRSP, 2003). Based on this assessment, a new document, the Growth and Employment Strategy Paper was produced (GESP, 2010). Also called Vision 2035, the GESP outlines the goals of the government for the country's growth and development, with the main target being that the country becomes an emerging nation by 2035 . By 2020 , the document opines, Cameroon should become not only a democratic state that respects diversity, but most importantly, a middle-income country with industries for manufacturing, mining and processing for example.

Vision 2035 is therefore a high level political and economic stand point of the government to promote job creation and sustainable development. It outlines how economic growth will be boosted between 2010 and 2020 through investments and improvements in technology, infrastructure, and modernized farm inputs to improve and increase productivity in agriculture, mining, key value chains and information and Communication Technology (ICT). It seeks to reduce unemployment from $76 \%$ to $50 \%$ by 2020 by ensuring that tens of thousands of jobs are created. This ambitious plan it is hoped, will be guided through success by the TVET sector. Unfortunately, there is little evidence that the GESP is achieving its targets. It is possible, at least in part, that poor policy implementation especially linked to a poor quality of education in general and TVET in particular is the reason behind this observed slow achievement of the GESP targets. 
To be proactive, considering a possible failure of the GESP and based on his vision to see Cameroon become an emerging nation by 2035, the Head of State during his re-election bid in 2011 made a policy declaration that Cameroon was going to become a vast construction site from January 2012. The immediate result of this declaration was an increase in the creation of Government Technical Colleges (Efande, 2015). For example, and as a direct response to the Head of States policy declaration, the Prime Minister signed decision No 2011/2141/PM of 05/08/2011 creating sixty-five new Government Secondary Technical Colleges (GTC) while a second Prime Ministerial Decision N ${ }^{\circ}$ 2011/2142/PM of 05/08/2011 transformed twenty-eight GTCs into Government Technical High Schools (GTHS). The schools were then authorized to go operational the same year by the Minister of Secondary Education with very little or no infrastructure and teachers. What one finds difficult to comprehend is the rush in implementing this policy declaration without any stakeholder consultations to identify the needs of trainees and employers, the availability of resources and the strategies for implementation to ensure success.

Thus, what seems to be happening is that the creation and opening of these schools is not governed by any clear development or budgetary plans. Rather, we reason that political considerations override the need for quality, resulting to the implementation of exhortation instruments without adequate resources or control mechanisms with schools opening without trained and quality teachers and equipment. For example, testimonies from one School Head revealed that the school was created on the 13/08/2009, authorized to go functional on the 21/09/2009 and effectively opened its doors to students on the 30/09/2009 with three departments; Accounting Service Clerk (ASC) with one teacher, Building Construction (BC) with one teacher and Electricity (ELEC) with no teacher. Currently, the school has five departments with only three teachers.

In-spite-of the prevalence of similar examples across the country, TVET schools continue to be created, opened and upgraded every year (Efande, 2015). Once such conditions prevail, children could be subjected to poor quality teaching based on inappropriate or poorly developed curriculum in ill-equipped schools and therefore graduate without acquiring the necessary skills for employment. Equitable access to quality teaching to ensure proper learning of skills for the world of work thus remains a worry. "There is little point expanding access to education unless there is reasonable quality" (Klees, 2002). Agreed, disparities in education exist across and within countries but ensuring access to quality teaching and learning should attract the attention of thoughtful minds in all edges of the world.

There is need therefore, to critically examine the quality of teachers who are called upon to impart knowledge and work skills to students, the major issues in TVET teacher supply and quality in Cameroon and the challenges these produce. But what exactly is meant by quality in education and what counts as teacher quality? What are the yardsticks to identify a quality teacher?

\section{Teacher Quality and Yardsticks to Determine a Quality Teacher}

\subsection{Concepts of Quality and Teacher Quality}

Quality as a concept has diverse meanings (Ayonmike et al, 2015; Oladipo, 2009). Synonymously, the words efficiency, effectiveness, equity and quality have been used, wrongly or rightly (Adams, 1993). The Cambridge dictionary defines quality as the characteristics of someone or something of high standards, while the Webster dictionary considers quality to be the degree of excellence, superior in kind. In education, quality is seen as a diverse and multidimensional concept which considers all the activities of an educational system, including but not limited to research and students, how good and efficient the teachers and academic programs are, how good and accessible the infrastructures and materials for teaching and learning are, how prepared are graduates to meet with life's challenges while providing solutions and services to the community, an academic environment which takes into consideration national cultural values and circumstances and international dimensions like the exchange of knowledge, interactive networking, mobility of teachers and students, and international research projects (Çelikten \& Yeni, 2005; Motala, 2001; Oladipo et al, 2009; Oyebade \& Adetoro, 2008; AU, 2007). Thus, one would imagine that quality or effective teachers should be teachers of high standards, excellent or superior in kind in conducting teaching learning transactions.

In TVET, quality is associated with the attainment of intended learning outcomes in conformity with the expectations of the stakeholders and can be ensured by the putting in place of quality assurance frameworks (Kingombe, 2012). This includes both internal and external quality monitoring and evaluation and ensures that qualifications, assessment and programmed delivery meet, and of necessity maintain specific laid down standards (Maajumdar et al, 2010; Tuck, 2007). In Cameroon, quality is assured by the Inspectorate General of Education.

On the contrary, very little consensus has been achieved on what counts as teacher quality, though there seem to be consensus in the literature on the need for quality teachers. Settled, teacher quality is contextual and far from being an innate characteristic or competence (Bates \& Townsend, 2007; Imig \& Imig, 2007). The unanswered question remains, what counts as teacher quality?

Clearly, there is no one size fits all definition for teacher quality (Green et al, 2018; Wiens et al, 2013). The teaching profession remains complex in terms of the pressure that is on the teacher to provide students with the required competencies (Baumert \& Kunter, 2013; Kleickmann et al., 2013). Quality teachers are those who are 
able to overcome these complexities and therefore provide students with the desired learning outcomes (Adoniou, 2013; Darling-Hammond \& Berry, 2006). To succeed, they use a combination of personal and professional skills and specialized knowledge acquired over time to overcome (McConney et al., 2012). Plus, they adhere to the benchmarks of effective teaching practice which highlight the principles of quality teaching, and demonstrate the expectations of quality teachers (Gigliotti, 2012). What becomes glaringly clear is that not only is the term quality, effective or excellent when used to describe a teacher difficult to define, but the criteria used to refer to someone as a quality teacher. Accepted, but if it remains elusive trying to get a universally accepted definition of who a quality teacher is, there might be some agreement on a combination of criteria or characteristics which, if one exhibits could qualify them to be referred to as a quality teacher.

\subsection{Criteria or Characteristics of Quality Teachers}

There are as many criteria for what should count as teacher quality as there are authors in the field of quality education. Nevertheless, to gain a better understanding of what counts as teacher quality, it seems important to consider not simply the experience, knowledge, repertoire of skills, and beliefs teachers must possess, but also the commitment and responsibility they need to have towards their students, colleagues and the teaching profession to be superior in kind (Bates \& Townsend, 2007; Imig \& Imig, 2007). All teachers have as duty to ensure that students are learning. More to this, quality teachers have as primary interest, to produce good students (Azer, 2005; Rice, 2003) and make the most significant impact in their student's life's (Gurney, 2007) by creating environments that are conducive to learning, provoking critical thinking, fostering self-directed learning, monitoring students' progress and raising their curiosity, while promoting teamwork (Barrows, 1996). They possess knowledge and skills in: academic reading, writing and mathematics, a good knowledge of the subject content they teach, are well grounded in pedagogy and hands-on teaching skills (Darling-Hammond \& Youngs, 2002) and possess a combination of competencies, skills or special attributes which contributes to effective teaching (Sahin \& Adiguzel, 2014; Wenglinsky, 2000).

Green et al. (2018) provides three interconnected dimensions of quality teachers that are observable through classroom practice. Each of these dimensions is associated with six interrelated elements (Hinde \& Reynolds, 2007; Ladwig, 2009; Liberante, 2012). The first dimension, Quality Learning Environment consist of the explicit quality criteria, social support, engagement, students' self-regulation, high expectations and students' direction. The second, Intellectual Quality, considers deep knowledge, higher order regulation, deep understanding, metalanguage, problematic knowledge and substantive communications. The third, significance considers background knowledge, inclusivity, connectedness, cultural knowledge, knowledge integration and narrative.

On their part, (McConney et al., 2012) summarize information from the Australian Professional Standards for Teachers highlighting the principles that have been agreed upon as well as the benchmarks for effective teachers and expectations required for future accreditation. These expectations are presented in three domains and seven standards. The first domain is Professional Knowledge with standards including the importance of the teacher knowing the students, how they learn and knowing the content and how to teach it. Next, is Professional Practice with standards being the need for the teacher to be able to plan and implement quality teaching and learning, create and maintain a supportive and safe learning environment (Gurney, 2007) as well as assess, provide feedback and report on students learning. Finally, the third domain, Professional Engagement has two standards requiring that the teacher be able to engage in both professional learning while maintaining a cordial relationship with their colleagues, parents of students and the community at large (Tileston, 2010).

Shulman \& Hutchings (2004) looked at teacher effectiveness from a somewhat different perspective. They argued that many a teacher program and researchers continue to stress on "research based" conceptions of teacher effectiveness to determine the capacity of a teacher to teach, focusing on basic abilities of the candidates with very little or no stress on subject content. They asked where the subject matter went to? and what happened to content? To Shulman \& Hutchings (2004), the use of some criteria as seen earlier to qualify teachers as effective or competent missis the real intension of these so called "teaching effectiveness" researches to identify patterns of teacher behavior that resulted in better learning and the improvement of student performance. Further, they regret that policy makers continue to base their development of evaluation criteria of teacher standards on the reports of these "teacher effectiveness"' reports without paying attention to their limitations. To boost their point, they argue that, scholars are fond of narrowing their scope, focusing their views and formulating questions that are simpler than how the world really is in practice to conduct their research. Through such oversimplification of the complex nature of the teaching profession, the subject matter which, par excellence should be the focus has been ignored. There is need for research to ask deeper questions on how teachers can convert subject matter from their knowledge as teachers into content of instruction. This conspicuous negligence that undermines or keeps out the subject matter from several research paradigms is what (Shulman \& Hutchings, 2004) now refers to as the "'missing paradigm" problem, a situation which begs for urgent attention from both researchers and policy makers. I seem to agree that it is important to separate content and pedagogy to ensure that each occupy their rightful positions. If so, it is time to roll back from emphasizing pedagogical content and ask the real questions on lesson content, the questions 
asked, and the explanations offered (Shulman \& Hutchings, 2004). Caution must be exercised in interpreting Shulmans \& Hutchings standpoint as they, in no way are settling for mere content knowledge without the pedagogical skills. Instead, they advocate for a proper chemistry between the two in proportions that benefit students understanding since "mere content is likely to be as useless pedagogically as content-free skills" (Shulman \& Hutchings, 2004).

In a separate study, Shulman \& Wilson (2004) traces the issue of quality teachers from how or when they learn to teach. He considers knowledge of the discipline, observation, learning experience, influence of past teachers, and student teachers to be important. On discipline, he highlights the importance of both content and teaching methods because, contrarily to other disciplines where subject knowledge is enough to become a professional, teaching is peculiar because "you must know, then know how to let someone know what you know". Thus, in teaching they argue that the discipline plays a dual role and needs practice, feedback and instruction (Shulman \& Wilson, 2004). Observation, they say is very important in determining teacher quality as the teacher spends several years observing how to teach before becoming a teacher. Further, learning to teach is like learning from experience, using a thoughtful trial and error approach. Plus, the influence of one's past teachers, shapes one into the kind of teacher one will become. Technically, University Professors and college tutors are all teacher trainers. They do so unconsciously because, every time they use good approaches to help students learn, it sticks and if these students become future teachers, they also try to use them. Therefore, good teachers do not simply tell students "what is so, but also deal with how it is so" (Shulman \& Wilson, 2004).

\section{What Quality TVET Courses Need to Consider}

Quality TVET courses are expected to provide a direct link between training institutions and employment by ensuring that teachers and trainees acquire the education and skills at the training colleges and practical training at workplaces, in line with the expectations of clients and stakeholder (Ryan, 2009; UNESCO, 2002). This ushers in the need for quality indicators and standards. Unfortunately, discrepancies in scholarship on the merits of a standard based quality TVET course has made it difficult to get universally accepted standards. It is argued that what works best for country " $A$ " might not for " $B$ " and the development of skilled manpower depends on the objectives, projections and trajectory of every nation (Gibb, 2003). To be effective, it was suggested that the development of courses should include all stakeholders' especially potential employers and be adapted to context. Further, there is need for each country to develop a systematic national qualification framework (Blom \& Meyers, 2003).

\subsection{Yardsticks or Indicators of Quality TVET Courses}

Quality remains a very broad policy area in education with many challenges (Ryan, 2009; UNESCO, 2002). First, quality is sometimes gauged through the relevance, credibility and utility of the training and considers the employability of the graduates, and the use of the skills acquired during training in the world of work, as well as the satisfaction of the employees and employers with the skills that are displayed by the graduates (Baker, 2000). Second, the educational and occupational background and training of teachers and the student/teacher ratio could be used as a proxy for quality courses. The amount of investment by state and private actors in TVET teacher training and retraining and the training of students is very important (Zeichner \& Cochran-Smith, 2005). A direct relationship has been established between quality teachers and quality teacher education programs (Adoniou, 2013). Hayward \& Homer (2015) opined that learners could effectively develop the skills and knowledge employers are searching for if TVET teachers are knowledgeable, skilled and experienced. Assuming that there is consensus that quality teachers represent an important factor in the teaching learning process, there is need for contextualized teacher training programs to bridge the gap between the conditions under which teachers are trained and the realities of the classrooms where they will be teaching to reduce the feeling of unpreparedness and increasing attrition (Bell et al., 2013; Le Maistre \& Paré, 2010; Vannatta et al., 2001). Also, it is imagined that the more access a student has to a teacher, the more effectively the student acquires skills as lower number of students per teacher indicates high quality teaching (Tang, et al., 2014). This remains a subject for debate.

Next, the ability to innovate and address knowledge gaps could be used to measure the quality of TVET courses. Access to suitable high-quality infrastructures and facilities and new technology like ICT, buildings, equipment's and learning materials are thought to serve as motivation for students and increases students' practical capabilities. The necessity for innovation and imperative for infrastructure and skilled teachers makes TVET courses very expensive and necessitate proper planning (Hayward \& Homer, 2015).

Fourth, the need for collaboration. Quality TVET courses incorporate enough time for practice out of the training institute as this allows the trainees to gain and demonstrate the skills they are expected to acquire by observing and practicing in industries or workplaces in a real life situation what they will be doing upon graduation (Simeoni, 2005). Evidence from existing literature indicates that, if quality assurance frameworks are respected, any training which balances theory and practice improves quality (Baumert \& Kunter, 2013; Guthrie et al., 2009; Haefeli, 2000). 
Further, quality courses should show both process and output (Shulman \& Hutchings, 2004; Shulman \& Wilson, 2004). Installing output indicators help to measure the changes in the learners resulting from the training. Thus, every training program should identify key training indicators to be used to verify if training was effective. This supports the need for quality assurance mechanisms to be put in place (Blom \& Meyers, 2003). Hoyle (2017) suggested the importance of a process indicator which spells out the expected results when the necessary inputs are managed as a process. Indicators should be developed in the presence of all the stakeholders (the government, industry, community and trainees) in a conducive environment that facilitates monitoring of the policy reforms (Van den Berghe, 1997; Bozo et al., 2009).

Finally, and based more from the trainee's perspective, higher graduation rates mean that there is internal efficiency of the training programs. This yardstick has been criticized to the advantage of those who think that skills, not qualifications should be measured (Huisman \& Westerheijden, 2010).

Based on the literature I have engaged with, it seems difficult to provide a unique set of criteria to define what a quality TVET course should look like. This is understandable because scholars, training providers or institutions, trainees and the government have different expectations and therefore use different methods to evaluate quality. It is therefore suggested that in attempting to develop and run quality TVET courses, every government should ensure that a system that incorporates the expectations of all stakeholders and results to employment and social integration is put in place. Further, a quality control system for monitoring and evaluation should be instituted and reviewed from time to time.

Having discussed what counts as teacher quality and quality TVET courses, it is important to find out if any, what issues exist in teacher supply and quality in Cameroon by looking at the current pathways to TVET teaching, the challenges that result and provide benchmarks.

\section{TVET Teacher Supply and Quality, Pathways to TVET Teaching, Challenges and Benchmarks 5.1. Major Issues in TVET Teacher Supply and Quality}

The goal of the Cameroon government is to see the nation emerge by 2035 . This requires an increase in the development of human capital. If diligently considered and applied, improving the quality of TVET teachers and teacher training colleges could help the youths become ready for jobs (Atchoarena \& Delluc, 2002) and speed up socio-economic and technological development (Ayonmike et al., 2015). This imposes the need for sufficient quality teachers. There is a general teacher shortage in TVET schools in Cameroon, with some schools having no teacher in particular options (Efande, 2015; Zouliatou, 2017). Difficulties in the recruitment and retention of TVET teachers had been observed elsewhere (Ingersoll, 2001; Smithers, 2000). The centralized system of governance in Cameroon with teachers recruited and distributed to the rest of the country doesn't seems to help the situation. While most schools in the city areas are overstaffed, those in semi urban areas are suffering from serious teacher shortages (Che, 2007; Efande, 2015). In addition, there are problems of poor salaries and the position of teachers in society. Further, poor financing, poor infrastructure, poor management, low efficiency in manpower and gender disparity makes a bad situation worse (Zouliatou, 2017).

A good knowledge of the current pathways to TVET teaching in Cameroon and the challenges that produces could pave the way for defining benchmarks to improve this sector and provide training opportunities that match the demands of employees and employers and facilitates Cameroons emergence by 2035.

\subsection{Current Pathways to TVET Teaching in Cameroon}

There are several routes to TVET teaching in Cameroon, the main one being through the teacher training colleges. Intake of teachers normally starts with a policy formation and decision for implementation that is made at the level of the state based on the need to reduce unemployment. An entrance examination is then launched specifying fields and the number of places available for that session based on budgetary considerations. Entrance into the different training colleges depends on qualifications and sometimes age. Holders of the General Certificate of Education Ordinary Level Technical, and Advanced levels Technical and its French equivalence the Probatoire and Baccalaureate can write the entrance examination into the Grade I Technical teachers training colleges without any age limits. Upon graduation, these teachers are meant to teach at the secondary level and in the home making or artisanal centers. Due to lack of better qualified personnel, some of these teachers teach in High Schools. Their absorption into the teaching corps is not automatic upon graduation. From time to time, the state launches special recruitments to provide them service numbers.

To enter the Higher Technical Teachers Training Colleges (HTTTC), it requires that candidates be holders of the Technical GCE Advanced level or Baccalaureate (for Secondary School teachers) and a Bachelor's degree for High school teachers. Agricultural pedagogy as of now has a special pathway since not many universities in Cameroon train students for bachelors in agriculture. Thus Agricultural Engineers are recruited and trained as teachers.

An alternative pathway to TVET teaching is through special competitive direct recruitment exams that the government launches to employ individuals who were trained on private sponsorship in the teacher training 
colleges or those with the corresponding level of certificates like Technical Advanced level, bachelor's or other equivalent engineering degrees.

\subsection{Challenges and Benchmarks for TVET in Cameroon}

Considering the multitude of problems facing developing countries like Cameroon, it is tempting to conclude that TVET is a prerequisite. Thus, it is important to review the challenges faced by TVET, then provide benchmarks.

Most nations seem to have realized the importance of globalisation and the need for global best practices and are aligning with it through benchmarking. Benchmarking is the process of evaluating current practices and processes of doing things and comparing them with the practices of different countries. In education, benchmarks help in setting educational standards in line with best practices with respect to the quality of knowledge, employable skills delivery and competencies and could be done through a comparative study of the educational practices of countries or using performance outcome indices (Magaji, 2017). It helps nations improve the quantity and quality of performance and eases monitoring while improving accountability (Ismail \& Hassan, 2013).

To ensure sustainable development in Cameroon, there is need for benchmarks in TVET. This requires making comparisons of the TVET teacher training programs and courses in Cameroon with that of other countries based on the curriculum, the delivery of content and the types of skills that are needed in the global market. Specifically, for quality TVET major areas include considering the development of the profession of TVET teachers, improving the system of teacher training and ensuring the quality of initial and in-service teacher training programs (Efande, 2015; Magaji, 2017).

\subsubsection{Developing the Profession of TVET Teachers}

The challenge here is related to teaching. Though TVET seems to be a policy priority to the government, there seem to be difficulties in translated this into practice (Efande, 2015). TVET teachers and professionals suffer from low public image as their job is not considered attractive in the society (Shulman \& Wilson, 2004). TVET teachers like those of general education have low salaries with very limited social benefits with their only advantage being a high job security and available pensions (Zouliatou, 2017). Symeonidis (2015) studied the status of teachers and the teaching profession and concluded that the socio-cultural and economic contexts, job security, salaries and working conditions, teacher's professional development, representation of the teaching profession, professional autonomy, social dialogue and involvement in decision-making was very low. In addition, findings on the national education demographic context revealed that the proposal for each country to spend minimum $6 \%$ of its GDP in education is not respected by most African countries (Hargreaves \& Flutter, 2013). For example, public spending on education as a share of the GDP in Cameroon was 1.93 in the year 2000 (Zouliatou, 2017). Teachers all over the world have expressed the need for society to appreciate the work they do (MacBeath, 2012). Interestingly, countries like South Korea, Singapore, and Finland where teachers enjoy high recognition have seen more effective teaching and learning (Symeonidis, 2015).

Based on these challenges, most Cameroonians consider TVET training and teaching only as a last resort when other career attempts have failed. Thus, low status reduces the probability of attracting quality manpower. This was the case in Ghana in the $90 \mathrm{~s}$, but the government put in place measures to improve the quality of teaching and learning as well as good governance (Anamuah-Mensah, 2000). Today, Ghana seems to be an example for Africa.

Benchmarks to improve the status and attractiveness of TVET teaching include, ensuring that there are clear routes on how teachers progress in the profession, providing a pathway on how one can become a TVET teacher while adjusting salaries to compensate staff that gain new skills and industry experience and not just through gaining a higher education qualification as is presently the case, elaborate a TVET teacher policy to govern TVET teacher education (Che, 2007; Zouliatou, 2017). There is need to change public perceptions on TVET from one meant for those with lower academic performance to that of one that leads to good jobs and better lives.

5.3.2. Improve TVET Teacher Training, Coherence and Management

An important challenge in TVET teacher education is teacher training geared mostly towards general education teachers, lack of specific funding for TVET teacher education as their funding is through government funds to state institutions or universities, thus leading to underfunding when compared to general education. Deprofessionalization of teachers sometimes is the result of rapid changes in educational policies including underfunding, recruitment of unqualified or contract teachers and poor accountability mechanisms (Verger \& Altinyelken, 2013).

Benchmarks include the need for increased capacity of TVET teacher training providers, the putting in place of frameworks for teacher training, introduce and ensure the respect of competence standards, and garner grassroots support and involve all stakeholders in the reform process. Thus, it might be necessary to establish and install coherence and management provisions by creating a national agency to coordinate the entire TVET system that should be placed under a single ministry. The agency should have representatives from all the stakeholders (Che, 2007; Zouliatou, 2017). 
5.3.3. Enhancing the Quality of Pre and In-Service Teacher Training With Relevant Curricular to Assure Relevance and Employability of Trainees

The challenges include trainings based on outdated programs which were constructed for general education, limited industry training or hands on practice, few opportunities for continued professional development, poor documentation on the motivations for becoming a TVET teacher, or choosing a TVET related career (Efange, 2015; Zouliatou, 2017). Lack of in-service training or professional development programs was reported as one of the problems of TVET in Sudan (Haramoto, 2017). In the absence of professional development programs, teachers lack ways of using technologies to keep abreast with teaching methods. To obtain high quality skills, there is need for appropriate and well adapted training equipments and practice for trainees. Also, qualified teachers with industry-based experience are needed to teach.

Benchmarks include ensuring stakeholder (industry-TVET-teacher education) dialogue, and involvement in the constant and timely update of pre and in-service curricula, fortify the relationship between employer and industry involvement in TVET through staff placements in the industry during initial and in-service teacher training, encouraging employers to participate in trade related courses and match TVET courses in general and teacher training in particular with the demands of the industry and other employers. In addition, provide incentives to teachers who carryout best practices and ensure good counseling services to potential trainees to enable them to make informed choices that are in line with their aptitudes but also in demand at the labor markets (Che, 2007; Efange, 2015; Haramoto, 2017; Zouliatou, 2017).

\section{Conclusion and Recommendation}

In-spite-of the challenges, quality TVET has the potential to facilitate the development and industrialization of Cameroons economy as it provides possibilities of developing practical solutions to foster sustainable development. Though benchmarking good practices from advanced systems is important, caution must be exercised since the context and circumstances differ. Therefore, Cameroon needs to be more innovative and inventive as it develops country specific practical solutions based on an objective and thorough analysis of the prevailing conditions and a robust TVET reform. This, combined with political stability and good governance may result in sustainable development. But, why is implementation of TVET policy in Cameroon a challenge? What are the challenges of working with TVET in Cameroon? Research to answer these questions is recommended as this should provide interesting answers needed to assist the government in its endeavors to become an emerging nation by 2035 .

\section{References}

Adams, D. (1993). Defining Educational Quality. Educational Planning, 9(3), 3-18.

Adoniou, M. (2013). Preparing teachers-the importance of connecting contexts in teacher education. Australian Journal of Teacher Education, 38(8), 4.

Afeti, G. (2010). Technical and vocational education and training for industrialization. Retrievedfromhttp.

Angrist, J. D., \& Lavy, V. (2001). Does teacher training affect pupil learning? Evidence from matched comparisons in Jerusalem public schools. Journal of Labor Economics, 19(2), 343-369.

Atchoarena, D., \& Delluc, A. (2002). Revisiting Technical and Vocational Education in Sub-Saharan Africa: An Update on Trends, Innovations and Challenges. New Trends in Technical and Vocational Education. ERIC.

Ayonmike, C. S., Okwelle, P. C., \& Okeke, B. C. (2015). Towards quality technical vocational education and training (tvet) programmes in Nigeria: challenges and improvement strategies. Journal of Education and Learning, 4(1), 25.

Azer, S. A. (2005). The qualities of a good teacher: how can they be acquired and sustained? Journal of the Royal Society of Medicine, 98(2), 67-69.

Baker, J. L. (2000). Evaluating the impact of development projects on poverty: A handbook for practitioners. The World Bank.

Barrows, H. S. (1996). Problem-based learning in medicine and beyond: A brief overview. New Directions for Teaching and Learning, 1996(68), 3-12.

Bates, R., \& Townsend, T. (2007). The future of teacher education: Challenges and opportunities. Handbook of Teacher Education, 727.

Baumert, J., \& Kunter, M. (2013). The COACTIV model of teachers' professional competence. In Cognitive activation in the mathematics classroom and professional competence of teachers (pp. 25-48). Springer.

Bell, R. L., Maeng, J. L., \& Binns, I. C. (2013). Learning in context: Technology integration in a teacher preparation program informed by situated learning theory. Journal of Research in Science Teaching, 50(3), $348-379$.

Bigala, J. (2006). The challenges of improving the quality of education of teachers. Nkumba University Journal, $1,103-114$.

Blom, K., \& Meyers, D. (2003). Quality indicators in vocational education and training: International perspectives. National Centre for Vocational Education Research. 
Bozo, D., Damian, R., Gonzalez, C. de la R., Helle, E., Imoda, F., Kohler, A., Shopov, T. (2009). Current Trends in European Quality Assurance. ENQA Workshop Report 8. ERIC.

Çelikten, M., Şanal, M., \& Yeni, Y. (2005). Teaching profession and its characteristics. Erciyes University, Institute of Social Sciences Journal, 19(2), 207-237.

Che, S. M. (2007). Technical and Vocational Education in Cameroon and Critical Avenues for Development. Research in Comparative and International Education, 2(4), 333-345. https://doi.org/10.2304/rcie.2007.2.4.333

Commission on the Private Sector. (2004). Unleashing entrepreneurship: making business work for the poor. United Nations Pubns.

Cooper, C. W. (2006). Refining social justice commitments through collaborative inquiry: Key rewards and challenges for teacher educators. Teacher Education Quarterly, 33(3), 115-132.

Darling-Hammond, L., \& Berry, B. (2006). Highly qualified teachers for all. Educational Leadership, 64(3), 14.

Darling-Hammond, L., \& Youngs, P. (2002). Defining "highly qualified teachers": What does "scientificallybased research" actually tell us? Educational Researcher, 31(9), 13-25.

Efande, L. J. (2015). Expansion Policy of Secondary Technical Education as a Correlate to the Acquisition of Basic Technical Skills by Students in Cameroon. Journal of Education and Practice, 6(35), 8-16.

Gibb, J. (2003). What impact is implementing a quality system having on the vocational education and training classroom? National Centre for Vocational Education Research.

Gigliotti, A.-R. (2012). Quality teaching and learning in the educational context: Teacher pedagogy to support learners of a modern digital society. Journal of Student Engagement: Education Matters, 2(1), $78-84$.

Green, C., Eady, M., \& Andersen, P. (2018). Preparing quality teachers. Teaching \& Learning Inquiry, 6(1), 104125. https://doi.org/10.20343/teachlearninqu.6.1.10

GESP. 2010. Growth and Employment Strategy Paper, Cameroon.

Gurney, P. (2007). Five factors for effective teaching. New Zealand Journal of Teachers' Work, 4(2), 89-98.

Guthrie, H., Harris, R., Simons, M., \& Karmel, T. (2009). Teaching for technical and vocational education and training (TVET). In International handbook of research on teachers and teaching (pp. 851-863). Springer.

Haefeli, K. (2000). Vocational Education in Switzerland: Facts, Figures and Prospects.

Haramoto, Y. (n.d.). Challenges of TVET in Developing Countries with a Case Study of Korea's Aid in Sudan.

Hargreaves, L., \& Flutter, J. (2013). The Status of Teachers and the Teaching Profession: A desk-study for Education International. Unpublished manuscript, Department of Education.

Hayward, G., \& Homer, M. S. (2015). Profile of the science, engineering and technology teaching workforce in the college sector in England.

Hinde McLeod, J., \& Reynolds, R. (2007). Quality teaching for quality learning: Planning through reflection.

Hoyle, D. (2017). ISO 9000 Quality Systems Handbook-updated for the ISO 9001: 2015 standard: Increasing the Quality of an Organization's Outputs. Routledge.

Huisman, J., \& Westerheijden, D. F. (2010). Bologna and quality assurance: progress made or pulling the wrong cart? Quality in Higher Education, 16(1), 63-66.

Ibrahim, M. Z., Ab Rahman, M. N., \& Yasin, R. M. (2012). Assessing students perceptions of service quality in technical educational and vocational training (TEVT) institution in Malaysia. Procedia-Social and Behavioral Sciences, 56, 272-283.

Imig, D. G., \& Imig, S. R. (2007). Quality in teacher education: Seeking a common definition. In Handbook of teacher education (pp. 95-112). Springer.

Ingersoll, R. M. (2001). Teacher turnover and teacher shortages: An organizational analysis. American Educational Research Journal, 38(3), 499-534.

International Labour Organisation, G. (Switzerland). (1977). Meeting Basic Needs: Strategies for Eradicating Mass Poverty AndUnemployment. ILO Publications.

Ismail, A., \& Hassan, R. (2013). Issue and Challenges of Technical and Vocational Education and Training in Malaysia for Knowledge Worker Driven (pp. 1-2). Presented at the National Conferences on Engineering Technology (NCET).

Kajubi, W. S. (1971). New directions in teacher education in East Africa. International Review of Education, 17(2), $197-210$.

Kingombe, C. (2012). Lessons for developing countries from experience with technical and vocational education and training. Economic Challenges and Policy Issues in Early Twenty-First-Century Sierra Leone, 278-365.

Klees, S. J. (2002). World Bank education policy: new rhetoric, old ideology. International Journal of Educational Development, 22(5), 451-474.

Kleickmann, T., Richter, D., Kunter, M., Elsner, J., Besser, M., Krauss, S., \& Baumert, J. (2013). Teachers' content knowledge and pedagogical content knowledge: The role of structural differences in teacher education. Journal of Teacher Education, 64(1), 90-106.

Krueger, A. B., \& Lindahl, M. (2001). Education for growth: Why and for whom? Journal of Economic Literature, 
39(4), 1101-1136.

Ladwig, J. G. (2009). Working backwards towards curriculum: On the curricular implications of quality teaching. The Curriculum Journal, 20(3), 271-286.

Law of Orientation of Education in Cameroon (1998). Law Number 98/004 of 14th April 1998: To Lay down Guidelines on Education in Cameroon.

Le Maistre, C., \& Paré, A. (2010). Whatever it takes: How beginning teachers learn to survive. Teaching and Teacher Education, 26(3), 559-564.

Liberante, L. (2012). The importance of teacher-student relationships, as explored through the lens of the NSW Quality Teaching Model. Journal of Student Engagement: Education Matters, 2(1), 2-9.

Maajumdar, S., Khambayat, R. P., Tsesoro-Gayondato, T., \& Solla, R. (2010). Integrating quality assurance in TVET system in support of qualifications framework (Vol. 30, p. 2013). Presented at the International Conference on Harnessing Qualifications Framework towards Quality Assurance in TVET. Retrieved October.

MacBeath, J. (2012). Future of teaching profession. Education International Brussels.

Magaji, Z. B. (2017). Benchmarks in Technical Vocation Education and Training (TVET) for Sustainable National Development in Nigeria, 3, 9.

Marope, P. T. M., Chakroun, B., \& Holmes, K. (2015). Unleashing the potential: Transforming technical and vocational education and training. UNESCO Publishing.

McConney, A., Price, A., \& Woods-McConney, A. (2012). Fast Track Teacher Education: A Review of the Research Literature on" Teach For All" Schemes. Online Submission.

Mclean, R., \& David, N. (2009). International handbook of education for the changing world of work: Bridging academic and vocational learning. Retrieved July 2013.

Motala, S. (2001). Quality and indicators of quality in South African education: a critical appraisal. International Journal of Educational Development, 21(1), 61-78. https://doi.org/10.1016/S0738-0593(00)00014-6

Ngoh, V. (2000). The Political Evolution of Cameroon, 1884-1961. https://doi.org/10.15760/etd.2924

Okorafor, A., \& Nnajiofo, F. (2017). TVET POLICIES AND PRACTICES IN NIGERIA: WHY THE GAP. European Journal of Education Studies.

Oladipo, A., Adeosun, O., \& Oni, A. (2009). Quality assurance and sustainable university education in Nigeria.

Oviawe, J. I., Uwameiye, R., \& Uddin, P. S. (2017). Bridging Skill Gap to Meet Technical, Vocational

Education and Training School-Workplace Collaboration in the 21 st Century. International Journal of Vocational Education and Training Research, 3(1), 7.

Oyebade, S., Oladipo, S., \& Adetoro, J. (2008). Determinants and Strategies for Quality Assurance in Nigerian University Education (Vol. 13). Presented at the second HERNET conference at IITA Ibadan, Citeseer.

Poverty Reduction Strategy Paper (PRSP) Cameroon. (2003). IMF. Available at https://wwwimf.org/external/pubs/ft/scr/2003/cr03249.pdf

Rice, J. K. (2003). Teacher quality: Understanding the effectiveness of teacher attributes. ERIC.

Rots, I., Kelchtermans, G., \& Aelterman, A. (2012). Learning (not) to become a teacher: A qualitative analysis of the job entrance issue. Teaching and Teacher Education, 28(1), 1-10.

Ryan, R. (2009). Making VET in Schools work: a review of policy and practice in the implementation of vocational education and training in Australian schools. The Journal of Educational Enquiry, 3(1).

Sahin, A., \& Adiguzel, T. (2014). Effective Teacher Qualities from International Mathematics, Science, and Computer Teachers' Perspectives. Eurasia Journal of Mathematics, Science \& Technology Education, 10(6).

Shulman, L. S., \& Hutchings, P. (2004). Teaching as community property: Essays on higher education. JosseyBass.

Shulman, L. S., \& Wilson, S. M. (2004). The wisdom of practice: Essays on teaching, learning, and learning to teach (Vol. 8). Jossey-Bass Inc Pub.

Simeoni, G. N. (2005). The role and function of apprenticeship training and cooperative education in British Columbia.

Smithers, A., Robinson, P., \& University of Liverpool/Centre for Education and Employment Research. (2000). Coping with teacher shortages. Centre for Education and Employment Research.

Sofoluwe, A. O. (2013). Re-engineering vocational and technical education (VTE) for sustainable development in North Central Geo-Political Zone, Nigeria. Educational Research and Reviews, 8(19), 1842-1849.

Symeonidis, V. (2015). The status of teachers and the teaching profession. Education International Research Institute: Belgium.

Tang, S. Y., Cheng, M. M., \& Cheng, A. Y. (2014). Shifts in teaching motivation and sense of self-as-teacher in initial teacher education. Educational Review, 66(4), 465-481.

Tchombe, T. M. (2001). Structural reforms in education in Cameroon. Unpublished Policy Paper. Accessed Online. Tilak, J. B. (2002). Education and poverty. Journal of Human Development, 3(2), 191-207.

Tileston, D. W. (2010). Ten Best Teaching Practices: How brain research and learning styles define teaching 
competencies. Corwin Press. tor al Board, E. (n.d.). Journal of Education and Practice.

Tuck, R. (2007). An introductory guide to national qualifications frameworks. ILO.

UNESCO. (2014). Teaching and learning: Achieving quality for all.

UNESCO Institute for Statistics. (2006). Teachers and educational quality: monitoring global needs for 2015 (Vol. 253). UNESCO Inst for Statistics.

UNESCO. International Centre for Technical and Vocational Education and Training (UNESCO-UNEVOC) Infocus Programme on Skills, K. and E. (2002). Technical and vocational education and training for the twenty-first century: UNESCO and ILO recommendations.

Union, A. (2007). Developing an African higher education quality rating system. Retrieved August, $20,06-10$.

Van den Berghe, W. (1997). Indicators in Perspective. The Use of Quality Indicators in Vocational Education and Training. CEDEFOP Document. ERIC.

VANNATTA, R., BEYERBACH, B., \& WALSH, C. (2001). From teaching technology to using technology to enhance student learning: Preservice teachers' changing perceptions of technology infusion. Journal of Technology and Teacher Education, 9(1), 105-127.

Verger, A., \& Altinyelken, H. K. (2013). Global education reforms and the new management of teachers: A critical introduction. Global Managerial Education Reforms and Teachers, 1.

Wenglinsky, H. (2000). How teaching matters: Bringing the classroom back into discussions of teacher quality.

Wiens, P. D., Hessberg, K., LoCasale-Crouch, J., \& DeCoster, J. (2013). Using a standardized video-based assessment in a university teacher education program to examine preservice teachers knowledge related to effective teaching. Teaching and Teacher Education, 33, 24-33.

Yildirim, A., \& Simsek, H. (1997). A Qualitative Assessment of Curriculum Development Process at Secondary Vocational Schools in Turkey.

Zeichner, K. M., \& Cochran-Smith, M. (2005). Studying teacher education: The report of the AERA panel on research and teacher education. Lawrence Erlbaum Associates.

Zouliatou, M. (2017). TVET and Economic Development in Cameroon: Lessons from China. Journal of Education and Practice, 8(33), 178-189 